\title{
WATERRESTRICTION IN GOATS DURING HOT-DRY SEASONIN THE HUMID TROPICS: FEED INTAKE AND WEIGHT GAIN
}

\author{
RESTRICCIÓN DE AGUA EN CABRAS EN EL TRÓPICO HÚMEDO DURANTE LA \\ ESTACIÓN SECA Y CÁLIDA: INGESTIÓN DE ALIMENTO Y GANANCIA DE PESO
}

\author{
Abioja, M.O. ${ }^{1 *}$, Osinowo, O.A. ${ }^{1}$, Adebambo, O.A. ${ }^{2}$, Bello, N.J. ${ }^{3}$ and Abiona, J.A. ${ }^{1}$ \\ ${ }^{1}$ Department of Animal Physiology. College of Animal Science and Livestock Production. University of \\ Agriculture. P.M.B. 2240. Abeokuta. Nigeria. *dimejiabioja@yahoo.com \\ ${ }^{2}$ Department of Animal Breeding and Genetics. College of Animal Science and Livestock Production. \\ University of Agriculture. P.M.B. 2240. Abeokuta. Nigeria. \\ ${ }^{3}$ Department of Water Resources Management and Agrometeorology. University of Agriculture. P.M.B. \\ 2240. Abeokuta. Nigeria.
}

\section{AdDitiOnAL KEYWORDS}

West African Dwarf goat. Red Sokoto goat.

\section{SUMMARY}

Twelve non-pregnant female goats (West African Dwarf, WAD and Red Sokoto, RS) were used to investigate the effect of volumetric $(0 \%$, $33 \%$ and $67 \%$ ) water restriction on feed intake and weight gain over a period of eight weeks. The goats are of 2 age groups: younger and older than 1 year. The experiment was arranged in a modified cross-over design with three treatment periods of 1 week each. In-between each treatment period was a 2-week wash-out period, when the effect of the previous was expected to have worn off. The average water intake (WI) was determined for the first 7 days of the experiment when all the animals were given water ad libitum. The 3 treatments were: (i) ad libitum supply of water every day; (ii) $33 \%$ reduction from average $\mathrm{Wl}$; and (iii) $67 \%$ reduction. Water drunk had positive and significant $(p<0.001)$ correlation with feed intake in young and old WAD $(r=0.490$ and 0.620 respectively) and RS ( $>1$ year old; $r=0.615$ ). All the four classes of goats showed positive highly significant $(p<0.001)$ correlation between water drunk and daily weight gain $(r=0.408,0.484,0.555$ and 0.422 respectively for WAD $(<1$ and $>1$ year old) and RS ( $<1$ and $>1$ year old goats).

\section{RESUMEN}

Doce cabras no preñadas (West African

Recibido: 2-4-08. Aceptado: 22-10-08.

\author{
Palabras clave adicionales \\ Cabra West African Dwarf. Cabra Red Sokoto.
}

Dwarf, WAD y Red Sokoto, RS) fueron empleadas para investigar el efecto de la restricción volumétrica $(0 \%, 33 \%$ and $67 \%)$ del suministro de agua sobre la ingestión de alimento y ganancia de peso durante ocho semanas. Los animales se agruparon por edad en menores y mayores de un año. El experimento se dispuso según un diseño cruzado, modificado con tres periodos de tratamiento de una semana cada uno. Entre cada periodo se intercaló uno de lavado de dos semanas durante el que se eliminaba el efecto del experimento precedente. La ingestión media de agua (WI) fue determinada para los siete primeros dias del experimento durante los cuales a todos los animales se suministraba agua ad libitum. Los tratamientos fueron: (i) suministro de agua ad libitum, (ii) reducción del 33\% sobre la ingestión media y (iii) $67 \%$ de reducción. El agua bebida mostró correlación positiva $(p<0,001)$ con la ingestión de alimento en las cabras WAD jóvenes ( $r=$ $0,490)$ y mayores $(r=0,620)$ y para las RS de más de un año $(r=0,615)$. Todas las cabras mostraron correlación positiva $(p<0,001)$ entre agua bebida y ganancia de peso (WAD: $<1, r=0,408$ y $>1,0,484$ y RS: $<1,0,555$ y $>1,0,422$ ).

\section{INTRODUCTION}

Nigerian livestock industries experience

Arch. Zootec. 59 (226): 195-203. 2010. 
economic losses because farm animals are reared in locations and seasons wherein water is not readily available and the effective temperature conditions venture outside their zones of thermal comfort. Goats in Nigeria encounter such high ambient temperature during hot-dry season prevailing in February and March (Abioja, 2005). It is also a time of water shortage when the little available pasture is dry and fibrous. West African Dwarf(WAD) goats are well adapted to the humid tropical conditions of the southwestern Nigeria while Red Sokoto (RS) goats are commonly found in the drier conditions of the northern Nigeria. The rate at which this affects the goats in the south-western Nigeria has not been fully understood.

Water deprivation during the season has been reported to affect respiratory and pulse rates in Tswana goats (Adogla-Bessa and Aganga, 2000), in WAD and RS goats (Abioja et al., 2007), and in Sudanaese desert sheep (Ahmed and Abdelatif, 1994). When animals were subjected to water restriction, they progressively lowered feed consumption which consequently affected their growth (Bohra and Ghosh, 1983; Aganga et al., 1989; Langhans et al., 1989; Abdelatif and Ahmed, 1994). This may not be compensated for after the water is subsequently made available. Many authors have reported a relationship between intakes of water and feed in ruminants (Ikhatua et al., 1992; Senn et al., 1996; Burgos et al., 2001). The perceived relationship might have resulted mainly from the role of water in digestion, elimination of the undigested residue and excretion of the waste products of metabolism. During the periods of water deprivation, Aganga et al. (1989) reported that jaw movement in sheep were drastically reduced, indicating impairment of rumination. Sheep deprived of water for more than $48 \mathrm{~h}$ were found to grow lean and felt dizzy(Umunna et al., 1981). Loss of weight was reported in Yankasa sheep (Aganga et al., 1989), fattening beef cattle (Togashi and Tanaka, 1979), dairy cows (Burgos et al., 2001) deprived water for varying lengths of time.
However, reports on WAD and RS goats are scarce and not readily available in literature. Moreover, most of the researches on water restriction are limited to the drier climate in the northern Nigeria and in other countries. Therefore, the present study was aimed at investigating the effect of water restriction on the feed intake and weight gain in WAD and RS goats during hot-dry season under the humid tropical conditions of south-western Nigeria.

\section{MATERIALSAND METHODS}

\section{EXPERIMENTALLOCATION}

This study was carried out at the Small Ruminant Unit of Teaching and Research Farms of University of Agriculture, Alabata Road, Abeokuta, Nigeria, located in the humid tropical climate (latitude $7^{\circ} 10^{\prime} \mathrm{N}$, longitude $3^{\circ} 2^{\prime} \mathrm{E}$ and altitude 76 metre above sea level and rain forest vegetation zone of south-western Nigeria. The mean annual rainfall, relative humidity and temperature are $1,037 \mathrm{~mm}, 82 \%$ and $34.7^{\circ} \mathrm{C}$ respectively.

\section{ANIMALSANDEXPERIMENTAL PROCEDURE}

Twelve non-pregnant does, 6 WAD (3 old and 3 young) and 6 RS (3 old and 3 young) used for this study are managed intensively in individual open-sided slatted floor pens and fed the same diet every morning $(08.00 \mathrm{~h})$ at $4 \%$ body weight. The composition of the diet given to the does is shown in table I. Water was given about the same time as the feed. The animals were allotted randomly to three treatments in a modified cross-over design (Lautier et al., 1988) with three treatment periods (TPs). The three treatments were: ad libitum supply of water ( $0 \%$ restriction, A), 33\% reduction from average water intake (B) and $67 \%$ restriction level $(\mathrm{C})$.

The first $7 \mathrm{~d}$ (preliminary period, PP) were for acclimatisation to experimental conditions and determination of average water intake of the goats. This was followed by 3 TPs of 7 days each. In-between each TP 
was a two weeks wash-out period (WP) during which the carry-over effects of earlier TP were expected to have wore off before another round of TP. The arrangement is in such a way that each animal received all the three treatments $(0 \%, 33 \%$ and $67 \%$ water restriction levels) at different TPs, one at a time.

\section{DATA COLLECTION}

Meteorological observations. The daily minimum and maximum ambient temperature, relative humidity, and wet- and dry-bulb temperatures at $08.00 \mathrm{~h}$ and $14.00 \mathrm{~h}$ were monitored using suitable thermometers. Relative humidity was calculated from wetand dry-bulb temperatures using a formula given by Palmer (2000). These were monitored for the 56 days the experiment lasted. The temperature-humidity index was determined from the data of temperature and relative humidity.

Live weight gain. The goats were weighed on the d 1 and 7 of each TP, and therefore the live weight gain of the animals were determined and recorded.

Table I. Composition of the diet given to the goats. (Composición de la dieta suministrada a las cabras).

\begin{tabular}{lc}
\hline Ingredient & $\%$ \\
\hline Wheat offal & 54 \\
Brewer's dried grain & 20 \\
Rice bran & 24 \\
Common salt & 1 \\
Bone meal & 1 \\
& \\
Calculated: & \\
Dry-matter & 87.7 \\
Crude protein & 15.7 \\
Crude fibre & 12.4 \\
Ether extract & 5.9 \\
Calcium & 0.47 \\
Phosphorus & 0.45 \\
\hline Metabolizable energy & $2092 \mathrm{kcal} / \mathrm{kg}$ \\
\hline
\end{tabular}

Feed and water intakes. Feed residue and water remnants were measured by $07.30 \mathrm{~h}$ for feed and water intake determination. The volume of water ingested with feed was estimated from the dry matter content of the diet. A watering was placed in an open pen to adjust for evaporation.

Feed conversion ratio calculation. The feed conversion ratio was taken as the ratio of weight gain to feed consumed.

Statistical design and analyses. The data on weight gain, feed intake, water intake, feed conversion ratio and ratio of water to feed were subjected to analysis of variance using a modified cross-over design. The daily mean temperature and relative humidity were included in the model as covariates. There were three TPs, which were taken as the replicates in the design. Pearson's correlation analysis was carried out between intakes of water and feed, weight gain, feed conversion ratio, mean temperature, relative humidity and temperature-humidity index for the four classes of goats used in the experiment. All the analyses were done using SYSTAT analytical computer package version 5.0 (SYSTAT, 1992).

\section{RESULTS}

The summary of climatic conditions during the experimental period is shown in table II. The minimum, maximum and mean temperatures averaged $26.5,36.3$ and $31.4^{\circ} \mathrm{C}$ respectively. The relative humidity averaged $81.1 \%$ while the mean temperature-humidity index was 98. Table III shows the least square means of the feed intake, daily weight gain and feed conversion ratio of goats subjected to water restriction. Water restriction had significant effect on the volume of water drunk $(\mathrm{p}<0.001)$, water drunk per metabolic weight $(p<0.001)$, water ingested in feed $(p<0.05)$, total water intake $(\mathrm{p}<0.001)$, total water intake per metabolic weight $(p<0.001)$, dry matter intake $(p<0.05)$, dry matter per metabolic weight $(p<0.001)$, water to feed ratio $(p<0.001)$, weight gain 
ABIOJA, OSINOWO, ADEBAMBO, BELLO AND ABIONA

Table II. Average weather conditions during the experimental period. (Condiciones climáticas medias durante el periodo experimental).

\begin{tabular}{lccccccc}
\hline Climatic factor & \multirow{2}{*}{ Mean \pm SEM } & \multicolumn{2}{c}{ Diurnal variation } & \multicolumn{3}{c}{ Treatment period } \\
& & $08: 00 \mathrm{~h}$ & $14: 00 \mathrm{~h}$ & 1 & 2 & 3 & \pm SEM \\
\hline Minimum temperature $\left({ }^{\circ} \mathrm{C}\right)$ & $26.5 \pm 0.45$ & - & - & 27.1 & 25.9 & 26.4 & 0.78 \\
Maximum temperature $\left({ }^{\circ} \mathrm{C}\right)$ & $36.3 \pm 0.58$ & - & - & 37.9 & 34.9 & 36.0 & 0.92 \\
Mean temperature $\left({ }^{\circ} \mathrm{C}\right)$ & $31.4 \pm 0.45$ & - & - & 32.5 & 30.4 & 31.2 & 0.74 \\
Relative humidity $(\%)$ & $81.1 \pm 1.58$ & $92.1 \pm 1.23$ & $70.1 \pm 2.40$ & 76.4 & 83.2 & 83.7 & 2.55 \\
Temperature-humidity index & $98.0 \pm 1.81$ & $88.6 \pm 1.81$ & $107.4 \pm 2.13$ & 100.3 & 94.6 & 99.2 & 3.14 \\
Dry-bulb temperature $\left({ }^{\circ} \mathrm{C}\right)$ & $29.2 \pm 0.44$ & $27.1 \pm 0.39$ & $32.7 \pm 0.55$ & 30.8 & 29.0 & 30.0 & 0.75 \\
Wet-bulb temperature $\left({ }^{\circ} \mathrm{C}\right)$ & $26.7 \pm 0.25$ & $26.0 \pm 0.29$ & $27.5 \pm 0.30$ & 26.7 & 26.2 & 27.3 & 0.43 \\
& & & & & & &
\end{tabular}

\pm SEM: standard error of mean.

$(\mathrm{p}<0.01)$ and feed conversion ratio $(\mathrm{p}<0.01)$. Goats placed on $67 \%$ level of water restriction exhibited lower values in all the parameters than goats on water ad libitum.

WAD had significantly lower volume of water drunk $(\mathrm{p}<0.05)$, water drunk per metabolic weight $(\mathrm{p}<0.05)$, water ingested in feed $(\mathrm{p}<0.01)$, total water intake $(\mathrm{p}<0.05)$, water intake per metabolic weight $(p<0.05)$ and dry matter intake than RS goats. Dry matter intake per metabolic weight, water to feed intake ratio, weight gain and feed conversion ratio were not significantly $(\mathrm{p}>0.05)$ affected by breed.

Effect of age was significant on water intake with young goats exhibiting signi-

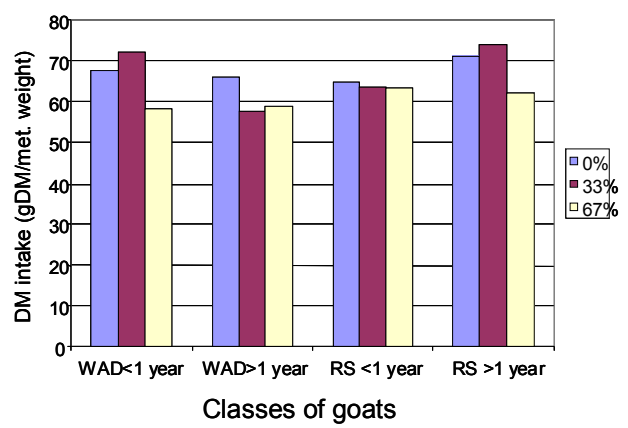

Figure 1. Effect of water restriction on DM intake in four classes of goats. (Efecto de la restricción hídrica sobre la ingestión de MS en cuatro clases de cabras). ficantly lower volume of water drunk $(p<0.001)$, water ingested in feed $(p<0.001)$, total water intake $(\mathrm{p}<0.001)$ and dry matter intake $(\mathrm{p}<0.001)$ than old animals. However, when these were considered at per metabolic weight, there were no significant $(\mathrm{p}>0.05)$ differences between young and the old goats. The ratio of feed to water intake was not significantly ( $p>0.05)$ affected by age. Weight gain and feed conversion ratio however, were significantly higher $(\mathrm{p}<0.001)$ for young goats than old ones. The goats older than one year were losing weight and therefore recorded negative FCR while the younger ones gained and recorded positive FCR during the treatment periods.

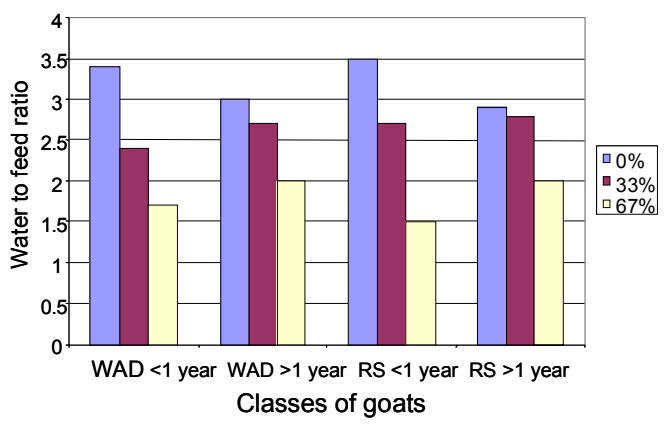

Figure 2. Effect of water restriction on water to feed ratio in four classes of goats. (Efecto de la restricción hídrica sobre la relación agua/ alimento en cuatro clases de cabras). 
Table III. Feed intake, weight gain and feed conversion ratio of WAD and RS goats of two age groups subjected to water restriction. (Ingestión de alimento, ganancia de peso y tasa de conversión de alimento de las cabras WAD y RS de dos grupos de edad sometidas a la restricción hídrica).

\begin{tabular}{|c|c|c|c|c|c|c|c|c|c|c|c|}
\hline Factors & ${ }^{*} \mathrm{MW}$ & WD & WDPM & WIF & TWI & TWIPM & $\mathrm{FI}$ & FIPM & WFR & WG & FCR \\
\hline \multicolumn{12}{|c|}{ Water restriction regime (W): } \\
\hline $0 \%$ & 6.6 & $1286.9^{a}$ & $196.1^{\mathrm{a}}$ & $111.5^{\mathrm{a}}$ & $1398.4^{a}$ & $213.0^{a}$ & $446.0^{a}$ & $67.6^{\mathrm{a}}$ & $3.2^{\mathrm{a}}$ & $27.4^{\mathrm{a}}$ & $0.056^{a}$ \\
\hline $33 \%$ & 6.7 & $1063.9^{b}$ & $157.3^{\mathrm{b}}$ & $111.4^{\mathrm{a}}$ & $1175.3^{b}$ & $174.0^{\mathrm{b}}$ & $445.8^{a}$ & $67.0^{\mathrm{a}}$ & $2.7^{\mathrm{b}}$ & $16.7^{a}$ & $0.047^{a}$ \\
\hline $67 \%$ & 6.6 & $614.5^{c}$ & $89.8^{c}$ & $100.7^{b}$ & $715.2^{c}$ & $104.9^{c}$ & $402.8^{b}$ & $60.6^{b}$ & $1.8^{\mathrm{c}}$ & $-108.3^{b}$ & $-0.222^{b}$ \\
\hline \pm SEM & 0.11 & 41.58 & 5.10 & 2.97 & 43.25 & 5.22 & 11.87 & 1.36 & 0.10 & 10.58 & 0.0223 \\
\hline \multicolumn{12}{|l|}{ Breed (B): } \\
\hline WAD & 6.6 & $937.5^{b}$ & $141.5^{\mathrm{b}}$ & $103.1^{b}$ & $1040.6^{b}$ & $157.4^{\mathrm{b}}$ & $412.5^{\mathrm{b}}$ & $63.4^{\mathrm{b}}$ & 2.5 & -17.5 & -0.023 \\
\hline RS & 6.7 & $1039.4^{\mathrm{a}}$ & $153.9^{a}$ & $112.6^{a}$ & $1152.1^{\mathrm{a}}$ & $170.5^{a}$ & $450.6^{a}$ & $66.8^{a}$ & 2.6 & -25.4 & -0.057 \\
\hline \pm SEM & 0.09 & 33.95 & 4.17 & 2.42 & 35.31 & 4.26 & 9.69 & 1.10 & 0.08 & 8.52 & 0.0176 \\
\hline \multicolumn{12}{|c|}{ Age group $(A)$ : } \\
\hline$<1$ year & 4.8 & $699.6^{b}$ & 146.0 & $77.7^{\mathrm{b}}$ & $777.4^{b}$ & 162.3 & $310.9^{b}$ & 65.1 & 2.6 & $18.3^{a}$ & $0.033^{a}$ \\
\hline$>1$ year & $8.5^{\mathrm{a}}$ & $1277.3^{a}$ & 149.4 & $138.0^{\mathrm{a}}$ & $1415.3^{a}$ & 165.7 & $552.1^{a}$ & 65.1 & 2.6 & $-61.1^{b}$ & $-0.113^{b}$ \\
\hline \pm SEM & 0.09 & 33.95 & 4.17 & 2.42 & 35.31 & 4.26 & 9.69 & 1.11 & 0.08 & 8.52 & 0.0176 \\
\hline \multicolumn{12}{|c|}{$\begin{array}{l}\text { Interaction }(\mathrm{W} \times \mathrm{B} \times \mathrm{A}) \text { : } \\
0 \% \text { WAD }\end{array}$} \\
\hline$<1$ year & $4.7^{b}$ & $912.9^{b}$ & $195.5^{\mathrm{ab}}$ & $78.3^{d}$ & $991.2^{\mathrm{b}}$ & $212.4^{\mathrm{ab}}$ & $313.3^{d}$ & $67.6^{\mathrm{abc}}$ & $3.4^{\mathrm{a}}$ & $66.7^{a}$ & $0.149^{a b}$ \\
\hline $\begin{array}{l}>1 \text { year } \\
0 \% \mathrm{RS}\end{array}$ & $8.6^{a}$ & $1651.9^{a}$ & $188.7^{\mathrm{ab}}$ & $141.6^{\mathrm{abc}}$ & $1793.5^{a}$ & $205.2^{\mathrm{ab}}$ & $566.6^{\mathrm{abc}}$ & $66.1^{\mathrm{abc}}$ & $3.0^{\mathrm{ab}}$ & $28.6^{b}$ & $0.007^{\mathrm{bcd}}$ \\
\hline$<1$ year & $4.7^{\mathrm{b}}$ & $986.3^{b}$ & $209.2^{\mathrm{a}}$ & $76.6^{d}$ & $1063.0^{\mathrm{b}}$ & $225.4^{\mathrm{a}}$ & $306.5^{d}$ & $64.9^{\mathrm{abc}}$ & $3.5^{\mathrm{a}}$ & $57.1^{\mathrm{a}}$ & $0.141^{\mathrm{ab}}$ \\
\hline $\begin{array}{l}>1 \text { year } \\
33 \% \text { WAD }\end{array}$ & $8.4^{\mathrm{a}}$ & $1596.5^{\mathrm{a}}$ & $191.2^{\mathrm{ab}}$ & $149.5^{\mathrm{ab}}$ & $1746.0^{\mathrm{a}}$ & $209.1^{\mathrm{ab}}$ & $597.8^{\mathrm{ab}}$ & $71.7^{\mathrm{ab}}$ & $2.9^{\mathrm{ab}}$ & $-42.9^{b}$ & $-0.074^{d e}$ \\
\hline$<1$ year & $4.6^{\mathrm{b}}$ & $725.2^{b}$ & $153.9^{b c}$ & $84.1^{d}$ & $809.3^{b c}$ & $172.1^{\mathrm{bc}}$ & $336.3^{d}$ & $72.7^{a}$ & $2.4^{\mathrm{bcd}}$ & $66.7^{a}$ & $0.183^{a}$ \\
\hline $\begin{array}{l}>1 \text { year } \\
33 \% \text { RS }\end{array}$ & $8.2^{\mathrm{a}}$ & $1072.4^{b}$ & $130.5^{\mathrm{cd}}$ & $118.6^{c}$ & $1191.0^{\mathrm{b}}$ & $145.0^{\text {cd }}$ & $474.4 \mathrm{c}$ & $57.8^{c}$ & $2.7^{a b c}$ & -128.6 & $-0.228^{e f}$ \\
\hline$<1$ year & $5.0^{\mathrm{b}}$ & $791.4^{b}$ & $157.4^{\mathrm{bc}}$ & $79.9^{d}$ & $871.2^{\mathrm{bc}}$ & $173.3^{b c}$ & $319.4^{d}$ & $63.7^{\mathrm{abc}}$ & $2.7^{a b c}$ & $47.6^{a}$ & $0.120^{\mathrm{abc}}$ \\
\hline $\begin{array}{l}>1 \text { year } \\
67 \% \text { WAD }\end{array}$ & $8.9^{a}$ & $1666.6^{a}$ & $187.3^{\mathrm{ab}}$ & $163.2^{\mathrm{a}}$ & $1829.8^{a}$ & $205.7^{a b}$ & $652.8^{a}$ & $73.9^{a}$ & $2.8^{a b c}$ & $81.0^{a}$ & $0.113^{a b c}$ \\
\hline$<1$ year & $4.9^{b}$ & $391.9^{c}$ & $79.9^{e}$ & $70.3^{d}$ & $462.3^{c}$ & $94.5^{\mathrm{e}}$ & $281.4^{d}$ & $58.4^{c}$ & $1.7^{d}$ & $-4.8^{a b}$ & $-0.032^{\mathrm{cd}}$ \\
\hline $\begin{array}{l}>1 \text { year } \\
67 \% \text { RS }\end{array}$ & $8.6^{a}$ & $870.5^{\mathrm{b}}$ & $100.7^{\mathrm{de}}$ & $125.7^{\mathrm{bc}}$ & $996.2^{b}$ & $115.4^{\mathrm{de}}$ & $502.9^{\mathrm{bc}}$ & $58.8^{\mathrm{bc}}$ & $2.0^{\mathrm{bcd}}$ & $-133.3^{c}$ & $-0.218^{e f}$ \\
\hline$<1$ year & $4.9^{b}$ & $390.0^{c}$ & $80.3^{e}$ & $77.2^{\mathrm{d}}$ & $467.2^{c}$ & $96.1^{\text {de }}$ & $308.7^{d}$ & $63.2^{\mathrm{abc}}$ & $1.5^{d}$ & $-123.8^{c}$ & $-0.363^{f}$ \\
\hline$>1$ year & $8.2^{\mathrm{a}}$ & $805.7^{b}$ & $98.1^{\text {de }}$ & $129.5^{\mathrm{bc}}$ & $935.2^{b}$ & $113.6^{\mathrm{de}}$ & $518.0^{\mathrm{bc}}$ & $62.1^{\mathrm{abc}}$ & $2.0^{\mathrm{cd}}$ & $-171.4^{c}$ & $=-0.276$ \\
\hline \pm SEM & 0.21 & 83.16 & 10.21 & 5.93 & 86.50 & 10.44 & 23.73 & 2.71 & 0.20 & 20.94 & 0.0433 \\
\hline
\end{tabular}

a,b,c Column means with different superscripts differ significantly $\mathrm{p}<0.05$; ${ }^{*} \mathrm{MW}=$ metabolic weight; $\mathrm{WD}=$ water drunk by goats $(\mathrm{ml})$; WDPM= water drunk per metabolic weight $\left(\mathrm{ml} / \mathrm{W}_{\mathrm{kg}}{ }^{0.75}\right) ; \mathrm{WIF}=$ water in feed $(\mathrm{ml}) ; \mathrm{TWI}=$ total water intake $(\mathrm{ml}) ; \mathrm{TWIPM}=$ total water intake per metabolic $\left(\mathrm{ml} / \mathrm{W}_{\mathrm{kg}}{ }^{0.75}\right) ; \mathrm{Fl}=$ dry matter intake (gDM); FIPM= dry matter intake per metabolic weight $\left(\mathrm{gDM}^{\mathrm{W}} \mathrm{W}_{\mathrm{kg}}{ }^{0.75}\right)$; WFR= ratio of total water intake to dry matter intake; $\mathrm{WG}=$ weight gain $(\mathrm{g} /$ day); $\mathrm{FCR}=$ feed conversion ratio. 


\section{ABIOJA, OSINOWO, ADEBAMBO, BELLO AND ABIONA}

Figures 1 to 4 show the effect of water restriction on DM intake, water to feed ratio, daily weight gain and FCR for the four classes of goats (WAD $<1$ year, WAD $>1$ year, $\mathrm{RS}<1$ year and $\mathrm{RS}>1$ year old goats) used in this experiment. Figure 1 shows DM intake in all the four classes of goats subjected to $67 \%$ restriction level was consistently lower than those that received water ad libitum. For water to feed ratio, the ratio decreased as the level of water restriction increased from $0 \%$ to $67 \%$ in all the four classes of goats (figure 2). All goats subjected to highest level of water restriction in this study grew lean, losing weight ranging between 4.8 and $171.4 \mathrm{~g} / \mathrm{d}$. In WAD goats $>1$ year of age, $33 \%$ water restriction also caused a loss of weight of $128.6 \mathrm{~g} / \mathrm{d}$ (figure 3). FCR followed the same pattern as in weight gain (figure 4).

Water drunk had positive and highly significant $(p<0.001)$ correlation with feed intake in WAD $(<1$ and $>1$ year old; $r=0.490$ and 0.620 respectively) goats and RS $(>1$ year old; $r=0.615)$, but not $(p>0.05)$ with $R S$ $(p<0.001)$ correlation between water drunk and daily weight gain $(\mathrm{r}=0.408,0.484,0.555$ and 0.422 respectively for $\operatorname{WAD}(<1$ and $>1$ year old) and $\mathrm{RS}(<1$ and $>1$ year old) goats). There was positive significant correlation

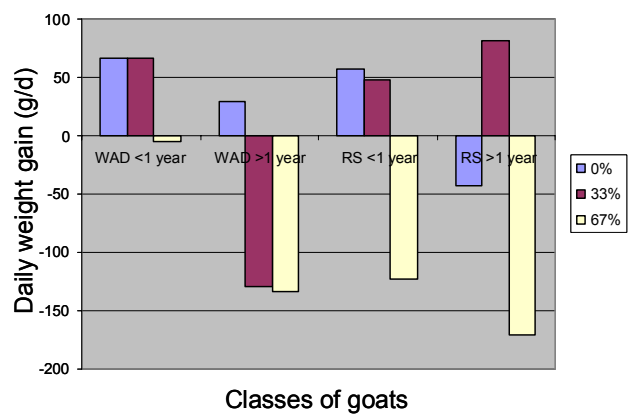

Figure 3. Effect of water restriction on daily weight gain in four classes of goats. (Efecto de la restricción hídrica sobre la ganacia diaria de peso en cuatro clases de cabras). between water intake and FCR for WAD goats younger than 1 year old $(p<0.05 ; r=$ $0.316)$, and the other three classes ( $\mathrm{p}<0.001$; $\mathrm{r}=0.432,0.549$ and 0.501 respectively.

\section{DISCUSSION}

The total water intake per metabolic weight of goats on $0 \%, 33 \%$ and $67 \%$ water restriction levels are 213.0, 174.0 and 104.9 $\left(\mathrm{ml} / \mathrm{W}_{\mathrm{kg}}{ }^{0.75}\right)$ respectively. Dry matter intake (gDM and $\mathrm{gDM} / \mathrm{W}_{\mathrm{kg}}{ }^{0.75}$ ) of goats decreased as water restriction level increased from $0 \%$ to $67 \%$. However, feed intake of animals on $0 \%$ was not different from $33 \%$. Goats subjected to $67 \%$ water restriction level ate $402.8 \mathrm{gDM}\left(60.6 \mathrm{gDM} / \mathrm{W}_{\mathrm{kg}}{ }^{0.75}\right)$ as against $445.8 \mathrm{gDM}\left(67.0 \mathrm{gDM} / \mathrm{W}^{\mathrm{kg}}{ }^{\mathrm{g}} .75\right)$ in $33 \%$ and $446.0 \mathrm{gDM}\left(67.6 \mathrm{gDM} / \mathrm{W}_{\mathrm{kg}}^{\mathrm{kg}} .75\right)$ in goats that received water ad libitum. The reduction in dry matter intake observed in the present study agrees with Atta (1977), Togashi and Tanaka (1979), Lautier et al. (1988), Aganga et al. (1989), Ikhatua et al. (1992), and Abdelatif and Ahmed (1994) that reported decreased feed intake in various ruminant species when water availability is limited. Gordon (1965) reported that feed intake of sheep declined noticeably by the second day without water. Bianca (1966) reported

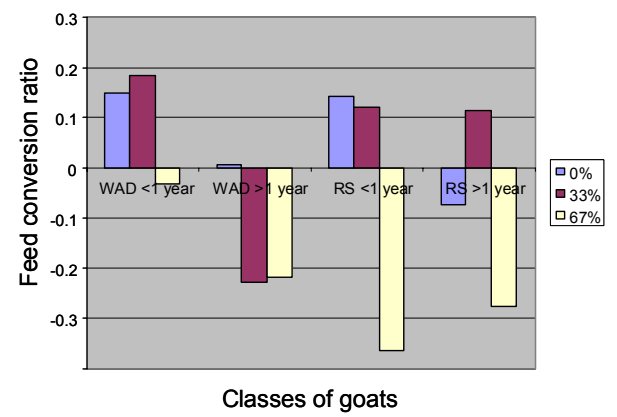

Figura 4. Effect of water restriction on feed conversion ratio in four classes of goats. (Efecto de la restricción hídrica sobre la tasa de conversión de alimento en cuatro clases de cabras). 
that by the fourth day of water deprivation, the hay intake of cattle declined by $27 \%$ of the control that received ad libitum. Cattle that normally eat $7.6 \mathrm{~kg}$ /day of feed ate 4.2 , $2.2,0.9$ and $0.5 \mathrm{~kg}$ on four successive days when water was removed totally (Weeth et al., 1967). Little et al. (1976) reported that a reduction of $40 \%$ in the amount of water allowed to dairy cows over a period of 6 days resulted in $16 \%$ reduction in feed intake. These show some similarities in the physiological adaptation of goats and cattle. Contrary to the result in the present study, Adogla-Bessa and Aganga (2000) reported that water restriction increased feed intake in Tswana goats. The difference in the results obtained by Adogla-Bessa and Aganga (2000) in Tswana goats might have occurred because of a few number of animals used in the present study with WAD and RS goats. Meanwhile, the authors of the former experiment focused on length of time water was withdrawn from the animals while the latter examined the effect of volumetric reduction in water supply. The reduction in dry matter intake from water restriction obtained now might be a result of the need of water for the physical softening of feed, digestion, removal of undigested residues and excretion of metabolic waste. Rumen hyper-tonicity has been proposed to be a major control of meal size in ruminants (Brouwer, 1965). Moreover, water is needed for heat dissipation through insensitive heat loss mechanisms (sweating and panting). Taking in more dry matter results in higher metabolic heat production in the body, which must be dissipated into the environment. During periods of reduced water intake in goats, the ingested material is retained in the rumen for longer periods than goats given water ad libitum (Brosh et al., 1987). The response of other breeds of ruminant to water restriction is not known.

The ratio of water to feed intake was significantly $(\mathrm{p}<0.001)$ lowered by water restriction, indicating that the goats that were deprived water took less of water per unit DM consumed. This agrees with the reports of Utley et al. (1970) in steers, Ikhatua et al. (1985) in zebu bulls, and AdoglaBessa and Aganga (2000) in Tswana goats. It was observed during the experiment that the goats in the restricted group normally took their ration once it was served, and ate to a point before going for water. And because they did not have a prior knowledge that water would not be available or restricted, they tended to take disproportionately more DM in relation to water available. Goats in ad libitum group had enough water to drink and usually had left-over.

However, Aganga et al. (1988) in contrary report from the result of the present study submitted that in Yankasa sheep, water deprivation resulted in higher water to feed ratio. The reduction in the ratio obtained in this study means that at $67 \%$ water restriction level, more DM was consumed by the goats. This may be due to the increase in the available space in the reticulo-rumen. Campling et al. (1961) had shown a direct relationship between rumen fill and intake in cows fed hay. At least for the meantime that the animal takes the water, the rumen is filled.

Weight gain decreased as water restriction level increased from $0 \%$ to $67 \%$. There was howeverno difference in weight gains between $0 \%(27.4 \mathrm{~g} / \mathrm{d})$ and $33 \%(16.7 \mathrm{~g} / \mathrm{d})$ restriction levels. At $67 \%$ restriction level, the weight gain was negative, showing the animals were losing weight. This observation confirms the findings of Umunna et al. (1981) in their study on sheep deprived of water during dry season and Lautier et al. (1988) in deer. Lowered daily weight gain as a result of water deprivation was also reported by other authors (Aganga, 1992; Adogla-Bessa and Aganga, 2000). The weight loss might be adduced to the reduction in DM intake. It may also be speculated that there might be reduced efficiency of digestion. Jaw movement was drastically reduced in goats that received highest level of water restriction, indicating that rumination may 


\section{ABIOJA, OSINOWO, ADEBAMBO, BELLO AND ABIONA}

be impaired by restricted access to water in goats. Feed conversion ratio was lower for animals that received highest level of water restriction (67\%) than $0 \%$ and $33 \%$ levels of restriction.Breed effect was significant on feed intake. RS goats consumed more dry matter per metabolic weight than WAD goats (66.8 vs. 63.4 gDM/ $/ \mathrm{W}_{\mathrm{kg}}^{0.75}$ respectively). This might have resulted from RS goats possessing larger digestive tract than the WAD goats. As well, RS goats are well adapted to the drier climate of the northern Nigeria (Adu et al., 1979) and therefore capable of coping with water deprivation than WAD goats that are commonly found in the humid climates. There were no differences however in water to feed ratio, daily weight gain and feed conversion ratio between WAD and RS goats. This shows that both breeds consumed water in the same proportion to DM intake. WAD lost $17.5 \mathrm{~g}$ per day while RS goats lost $25.4 \mathrm{~g}$ per day, hence the negative FCR.

Age had no effect on DM intake per metabolic weight (65.05 vs. $65.09 \mathrm{gDM} /$ $\mathrm{W}_{\mathrm{kg}}^{0.75}$ for goats $<1$ and $>1$ year respectively), though younger animals actually consumed smaller amount of feed than older ones. Water consumption was also in the same proportion with feed intake by the two age

\section{BIBLIOGRAPHY}

Abdelatif, A.M. and Ahmed, M.M.M. 1994. Water regime, thermoregulation, blood constituents and endocrine responses in Sudanese desert sheep. J. Arid Environ., 26: 171-180.

Abioja, M.O. 2005. Physiological and haematological responses of West African Dwarf and Red Sokoto goats to water regimes in the humid tropical conditions of south-western Nigeria. M. Agric. dissertation submitted to the Department of Animal Breeding and Genetics. University of Agriculture. Abeokuta. Nigeria.

Abioja, M.O., Osinowo, O.A., Adebambo, O.A., Bello, N.J. and Abiona, J.A. 2007. Physiological response of West African Dwarf and Red Sokoto goats to water restriction in the humid groups. In contrast, there were significant differences in weight gain and FCR between the goats $<1$ and $>1$ year. While young goats were gaining $18.3 \mathrm{~g}$ per day, the old ones were losing $81.1 \mathrm{~g}$ per day. Most of these effects were moreover recorded in goats subjected to $67 \%$ water restriction regime.

The positive significant correlation observed between feed and water intake corroborates the findings of Preston and Leng (1987) and Ikhatua et al. (1992). The perceived relationship between the two might be a result of the role water plays in digestion and excretion of metabolic wastes. Concerning the observed correlation between water and weight gain, the present study agrees with the fact that water deprivation caused loss of weight as reported by Umunna et al. (1981).

\section{CONCLUSION}

This study shows that water restriction affects the DM intake and weight gain of goats when the level of restriction reaches $67 \%$. Goats are able to cope with a reduction of one third of the average WI. All the goats subjected to $67 \%$ water restriction irrespective of class lost weight during the treatment periods.

tropics of south-western Nigeria. Abstract book of the Annual conf. of Animal Science Association of Nigeria (ASAN). Sepember, 2007. Obafemi Awolowo University, Ile-Ife. Nigeria.

Adogla-Bessa, T. and Aganga, A.A. 2000. Responses of Tswana goats to various lengths of water deprivation. South African J. Anim. Sci., 30: 87-91.

Adu, I.F., Buvanendran, V. and Lakpini, C.A.M. 1979. The reproductive performance of Red Sokoto goats in Nigeria. J. Agric. Sci., 93: 563567.

Aganga, A.A. 1992. Water utilization by sheep and goats in northern Nigeria. World Animal Review. FAO, 73: 9-14. 


\section{WATER RESTRICTION IN GOATS DURING HOT-DRY SEASON IN THE HUMID TROPICS}

Aganga, A.A., Alabi, O. and Momoh, M. 1988. Effect of water deprivation on nutrient digestibility, nitrogen retention and water excretion in Yankasa sheep and Maradi goats. Nig. J. Agric. Prod., 15: 139-143.

Aganga, A.A., Umunna, N.N., Oyedipe, E.O. and Okoh, P.N. 1989. Breed differences in water metabolism and body composition of sheep and goats. J. Agric. Sci., 113: 255-258.

Ahmed, M.M.M. and Abdelatif, A.M. 1994. Effects of regime of water and food intake on thermoregulation, food utilization and water economy in desert sheep. J. Arid Environ., 28: 147-153.

Atta, M.Y. 1977. Water metabolism in indigenous cattle, sheep and goats in Zaria, Nigeria. Ph. D dissertation Ahmadu Bello University, Zaria. In: Ahamdu Bello University thesis and dissertation abstracts (1962-1978). Kashim Ibrahim Library. ABU. Zaria. 294 pp.

Bianca, W. 1966. Heat tolerance in dehydrated steers. J. Agric. Sci., 66: 57-60.

Bohra, H.C. and Ghosh, P.K. 1983. Nitrogen metabolism in water restricted Marwari sheep of the Indian desert. J. Agric. Sci., 101: 735-739.

Brosh, A., Shkolnik, A. and Choshniak, I. 1987. Effects of infrequent drinking on the nitrogenous metabolism of Bedouin goats maintained on different diets. J. Agric. Sci.,109: 165-169.

Brouwer, E. 1965. Report of sub-committee on constants and factors. In: Proceeding of the $3^{\text {rd }}$ International Symposium on energy metabolism of farm animals. Troon EAAP Publ. 11: 441-443.

Burgos, M.S., Senn, M., Sutter, F., Kreizer, M. and Langhans, W. 2001. Effect of water restriction on feeding and metabolism in dairy cows. Am. J. Physiol.- REG I, 280: R418-R427.

Campling, R.C., Freer, M. and Balch, C.C. 1961. Factors affecting the voluntary intake of food by cows 2: The relationship between voluntary intake of roughages, the amount of digesta in the reticulo-rumen and the rate of disappearance of digesta from the alimentary tract. Brit. J. Nutr., 15: $531-536$.

Gordon, J.G. 1965. The effect of water deprivation upon the rumination behaviour of housed sheep. J. Agric. Sci., 64: 31-35.

Ikhatua, U.J., Dede, T.I. and Apumami, A.S. 1992. Water and feed utilization relationship in WAD (forest) goats of southern Nigeria. Nig. J. Anim. Prod., 19: 120-124.

Ikhatua, U.J., Ehoche, O.W. and Umoh, J.E. 1985. Effects of restricted water on feed intake, nutrient utilization and nitrogen metabolism in Zebu cattle. J. Agric. Sci., 105: 463-467.

Langhans, W., Senn, M., Meyer, A.H. and Scharrer, E. 1989. Feeding behaviour of pygm goats during water deprivation. Asian Austral. J. Anim., 2: 273-274.

Lautier, J.K., Dailey, T.V. and Brown, R.D. 1988. Effect of water restriction on feed intake of white-tailed deer. J. Wildlife Manage., 52: 602606.

Little, W., Sansom, B.F., Manston, R. and Allen, W.M. 1976. Effects of restricting water intake of dairy cows upon their milk yield, body weight and blood composition. Anim. Prod., 22: 329339.

Palmer, C. 2000. Humidity formulas. Today's Information Network, USA. (www.humidity.com). (12-5-2003).

Preston, T.R. and Leng, R.A. 1987. Matching ruminant production systems with available resources in the tropics and sub tropics. Penambul books. Armidale. Australia. pp. 98-101.

Senn, M., Gross-Lüem, S., Kaufmann, A. and Langhans, W. 1996. Effect of water deprivation on eating patterns of lactating cows fed grass and corn pellets ad libitum. Physiol. Behav., 60: 1413-1418.

SYSTAT. 1992. Systat analytical computer package, version 5.0 Systat Inc. USA.

Togashi, K. and Tanaka, S. 1979. The effects of water regime on physiological responses in fattening beef cattle. Jpn. J. Zootechn. Sci., 50: 320-327.

Umunna, N.N., Chineme, C.N., Saror, D.I., Ahmed, A. and Abed, S. 1981. Response of Yankasa sheep to various lengths of water deprivation. J. Agric. Sci., 96: 619-622.

Utley, P.R., Bradley, N.W. and Boling, J. 1970 Effect of restricted water intake on feed intake, nutrient digestibility and nitrogen metabolism in steers. J. Anim. Sci., 31: 130-135.

Weeth, H.J., Sawhney, D.S. and Lesperance, A.L. 1967. Changes in body fluids, excreta and kidney function of cattle deprived of water. J. Anim. Sci., 26: 418-423. 